\title{
An investigation of patterns of response and recovery among flood-affected businesses in the UK: a case study in Sheffield and Wakefield
}

\author{
N. Bhattacharya-Mis ${ }^{1} \&$ J. Lamond ${ }^{2}$ \\ ${ }^{1}$ Faculty of Science and Engineering, University of Wolverhampton, UK \\ ${ }^{2}$ Faculty of Environment and Technology, \\ University of West of England, UK
}

\begin{abstract}
Despite the increasing impacts of recurrent flooding, there is dearth of research involving businesses preparedness and recovery. This research therefore focused on investigating the patterns of preparedness and trends in recovery among business properties. A review of literature was performed primarily to recognize the gaps requiring investigation followed by identification of two case studies (Wakefield and Sheffield in the UK) for empirical data collection. The survey enquired about the level of preparedness among a sample of the flood-affected business community using a self-administered questionnaire. Questions addressed the type of mitigation and preparedness activities and measures that they engaged in and adopted for recovery along with factors like time cost of recovery and sources of finances. Results from the survey suggest that business interruption was highly influential in terms of differential cost and time of recovery. It was not the direct impact of flooding rather the under-researched and lesser-perceived business interruption through indirect factors that were more significant for cost and time of recovery. Furthermore, evidence of businesses relying highly on selffinance was also apparent from the survey. Knowledge gained from the survey for preparedness measures indicated that out of flood-affected samples that flood experience is an important indicator of preparedness and mitigation actions. The outcome of the research has highlighted some of the least researched phenomena in the flood-affected business property sector and can demonstrate the need for more widespread efforts to improve disaster recovery among businesses and a novel input for future research.
\end{abstract}

Keywords: businesses, flood risk, damage, disruption, preparedness, recovery. 


\section{Introduction}

Ensuring continuity of businesses in times of disaster is necessary for business sector and it is necessary to synthesize prevention and protection measures in a pre-disaster scenario in order to respond and recover faster during and after an event and ensure continuous business operation [1] . Reduction of direct impact among business enterprises require emergency relief services for cleaning up, rebuilding and restoring properties. On the other hand, mitigation of indirect effects demand financial assistance, employees' return to job, suppliers and consumer adjustment to the market, and essential service management. The Committee on Disaster Research in Social Sciences has rightly suggested that enterprises or businesses who are engaged in preparedness and mitigation activities will be less vulnerable to natural disasters [2]. In theory insuring property and businesses against flood damage can be treated as one of the effective tools of mitigation; however, literature suggest that about $90 \%$ of the small and medium enterprises (SME) in UK are under-insured [3]. Pitt's report after the 2007 flood event recommended the necessity of adoption of property level resistance and resilience measures for all types of properties in the UK [4]. Research has previously shown that business properties lack in such sources of protection against impacts of flooding $[5,6]$ but such research has been limited in scale and scope. Therefore, the main focus of this study is to further identify and investigate patterns of preparedness and link this to trends of recovery using a case study approach. The paper is structured in four sections. First, existing literature is reviewed to gather impression of the flood risk and response situation in general among flood plain population. Based on the rationale gained from literature review methodology for specific case study areas were discussed and finalized. This is followed by section on observed patterns of preparedness and recovery from the selected case studies and finally, recommendations for future studies were proposed before concluding remarks.

\section{Review of flood response and recovery}

The concept of response and recovery from disastrous event such as flooding incorporates certain basic factors: knowledge of the risk; monitoring and warning with ample time to respond; awareness and preparedness to cope with the impacts and recover [7, 8]. First of all it is pertinent to identify the critical assets that are exposed to risk and have higher vulnerability to decrease operational risk [9]. Apart from the direct protection of exposed assets, literature suggests that business preparedness and response to disasters can also be affected by indirect factors such as level of awareness regarding available protection measures and their long term sustainability; anticipation of actual risk and perception of being secure; as well as timely decision making of adaptation of risk reduction practices [10-12]. Table 1 lists some factors which are frequently associated with preparedness and recovery in literature.

Businesses at risk of flooding in general show lack of preparedness that affects their rate of recovery $[5,16,27]$. The issue of changing strategies towards risk 
Table 1: Review of main factors associated with preparedness and recovery.

\begin{tabular}{|l|l|l|}
\hline Factors & Insights from literature & $\begin{array}{l}\text { Literature } \\
\text { references }\end{array}$ \\
\hline $\begin{array}{l}\text { Low preparedness } \\
\text { and longer recovery }\end{array}$ & $\begin{array}{l}\text { Preparedness and precautionary measures } \\
\text { among businesses are generally low (especially } \\
\text { SME's). Firm characteristics play an important } \\
\text { role in preparedness. }\end{array}$ & {$[13-17]$} \\
\hline $\begin{array}{l}\text { Risk perception and } \\
\text { attitude }\end{array}$ & $\begin{array}{l}\text { Low level of preparedness as a result of low } \\
\text { perception of risk, inadequate } \\
\text { Lack of recognition of preparedness and } \\
\text { mitigation measures by affected population }\end{array}$ & {$[18-20]$} \\
\hline $\begin{array}{l}\text { Highly vulnerable } \\
\text { properties are more } \\
\text { prone to } \\
\text { preparedness }\end{array}$ & $\begin{array}{l}\text { Those at greatest risk adopt hazard adjustments. } \\
\text { This includes businesses with previous } \\
\text { experience of disaster had engaged in more } \\
\text { preparedness and mitigation activities. }\end{array}$ & {$[1,14,21,22]$} \\
\hline $\begin{array}{l}\text { More concentration } \\
\text { on direct damages } \\
\text { as preparatory } \\
\text { measures }\end{array}$ & $\begin{array}{l}\text { Businesses are more prone to prepare against } \\
\text { direct damages than disruption to business } \\
\text { operations. }\end{array}$ & {$[1,14]$} \\
\hline $\begin{array}{l}\text { Risk } \\
\text { communication }\end{array}$ & $\begin{array}{l}\text { Lack of risk communication can affect } \\
\text { preparedness and recovery; early response and } \\
\text { warning are pre-requisites }\end{array}$ & {$[23,24]$} \\
\hline Financial capacity & $\begin{array}{l}\text { Financial incapability can be a big barrier to } \\
\text { preparedness and recovery. Investment in } \\
\text { disaster preparedness can reduce short term } \\
\text { profitability. }\end{array}$ & {$[25,26]$} \\
\hline
\end{tabular}

reduction through appropriate flood response and recovery for flood plain population involves factors such as being kept well informed through media; early response to warnings; consideration of warning dissemination time and evacuation time from the building $[23,24]$. To respond to indirect effects of flooding, it is essential to recover and restore vital records (insurance papers, tax return documents, tracing orders etc.). This is greatly facilitated through appropriate preparation and backup in advance of flooding $[1,28]$ and such activities may be specified through a continuity plan. Financial constraint can make the recovery process take longer [26] therefore adequate insurance is indicated. .Without insurance, larger enterprises have greater financial capacity to respond to flood effects and therefore tend to recover faster from floods while smaller enterprises might suffer more as a result of their financial constraints [25, 26]. Factors such as reluctance of finance companies to supply loans for repair of the affected property and high premiums set by insurance companies for flood prone properties can prove to be fatal for the recovery process [24]. Such actions can have catastrophic impacts on many businesses; one report suggests that around $43 \%$ of the properties closed down after a disaster and about $29 \%$ of those closed down within two years [29]. Based on the insights gained from literature, the following section will detail the methodology adopted in collection of empirical data from two selected case study locations to analyse the situation of preparedness and recovery in flood-affected areas for business properties of flood plain population. 


\section{Methodology}

It was necessary to identify areas for empirical data collection which have a historical record of flooding and have a comparatively large population of commercial properties at risk. Case study approach (although being geographically limited) was appropriate for the purpose because of the scattered nature of flood-affected properties and the lack of publicly available national data sources with evidence of commercial properties affected by flooding in the past. Therefore to increase the probability of tracing a comparatively large sample a larger population at risk was selected through a systematic case study selection approach.This is general consensus in literature that better prepared businesses will fare well in case a disaster strikes [30-32]. The questionnaire survey enquired about the level of preparedness among flood-affected sample population by asking questions concerning type of mitigation and preparedness activities they are engaged in. Number of preparedness and mitigation measures was provided in the questionnaire with a range of activities to choose from. Enquiry was also done to observe whether the preparedness measures were adopted before or after any flood event.

\subsection{Case study areas}

The national assessment of flood risk in England states that the second area after London at highest risk of flooding with largest number of people living at risk is Yorkshire and Humber region [33]. Yorkshire and Humber region has a long history of flooding and flooding in 2007 caused record breaking disruptions in the area. It was mainly caused by heavy rainfall and river overflows. An Environment Agency data report released in November 2007 showed that number of businesses flooded in the region was 3718 which is the highest in the entire country [34]. Therefore, this area was selected as the area of interest for the research. The four worst-affected locations were identified in the region: Sheffield, Hull, Doncaster and Wakefield. In both Sheffield and Hull more than 1000 commercial properties were affected as a result of 2007 flooding. Sheffield was chosen as one of the case study areas because of the historical evidence of higher frequency of flooding in the area than Hull which was one of the essential factors for sampling area selection. In Doncaster not enough businesses were flooded and most of its vulnerable areas were residential in nature as compared to Wakefield. Therefore, Wakefield was chosen as the second case study location suitable for this study.

\subsection{Survey approach}

The primary unit of analysis for the research are commercial property occupiers. There was no readily available data set of the members of this target population that have been affected by direct or indirect sources of flooding from which a sample population could be selected. Therefore a sample set was constructed from a combination of different data sources. For example, available literature and flood risk maps were relied upon to build a picture of the areas affected. It was therefore difficult to determine the exact sample size relative to the target population since 
determination of sample frame was based mainly on indirect sources. The available information for the selected areas was historical flooding and approximate number of commercial properties at risk or affected by flooding in a particular event. Valuation office dataset was geographically projected to overlay the sampled population on maps to determine their level of risk for particular location. The sampling strategy employed was systematic sampling stratified by flood risk category delineated by Environment Agency maps. A remote delivery postal self-administered survey of 3660 occupiers of commercial buildings was performed in all risk zones within the floodplain of two selected case study areas. The variables selected for design of the survey instrument was based on the conceptual framework generated and operationalized based on review of literature. The questionnaire consisted of open and closed questions for different categories of variables (such as flood damage, preparedness, sources of recovery, property characteristics) were required to be measured for the analysis based on the operational framework.

\section{Results and discussion}

\subsection{Observed patterns of preparedness}

Knowledge gained from the overall scenario indicated that out of the 69 floodaffected responses 33 (48\%) undertook some sort of preparatory measures and 36 $(54 \%)$ did not engage in any of the given preparatory actions. Similarly, when the type of preparedness measures implemented by prepared part of the sample population were analysed it was apparent that they preferred easy to procure temporary preparatory measures and fewer long term permanent solutions for risk reduction. Other popular measures are Environment Agency flood warning and property and business insurance (see Figure 1).

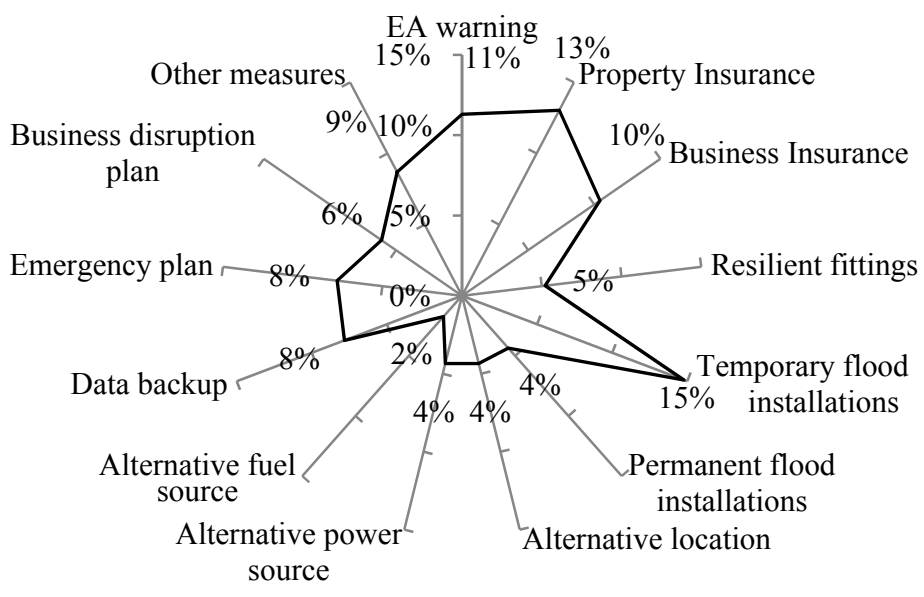

Figure 1: $\quad$ Preparedness measures adopted by flood-affected respondents. 
Temporary flood installations were largely adopted which were not adequate for higher magnitude of flooding. More than half (total 55\%) of business occupiers who adopted any sort of preparatory measures took up only one or two measures, $19 \%$ restricted themselves with 3 to 4 measures and 26\% were prepared for flooding with more than 4 different combination of measures. This shows that although taking measures for flood risk reduction is not very prevalent among occupiers there is certain group of business occupiers who have started preparing for the inevitable. Flood experience can be seen as having significant impact on the level of adoption of protection measures. An interesting pattern was observed based on the responses from the population who were flooded once and more than once in the study areas (Table 2).

Table 2: $\quad$ Flood experience vs. preparedness level.

\begin{tabular}{|l|c|c|}
\hline Flood experience & Percentage prepared & $\begin{array}{l}\text { Percentage prepared } \\
\text { before flood }\end{array}$ \\
\hline Flooded once & $39 \%$ & $26 \%$ \\
\hline Flooded twice & $88 \%$ & $71 \%$ \\
\hline Flooded more than twice & $100 \%$ & $60 \%$ \\
\hline Total & $62 \%$ & $43 \%$ \\
\hline
\end{tabular}

One hundred percent (100\%) of the people flooded more than twice have taken up some preparatory measures, $88 \%$ of those flooded twice have at least one measure, and $39 \%$ were prepared after only one event. The average number of measures adopted by businesses did not show much variance based on the level of experience. The range of number of adopted measures varied between 1.6 (flooded once), 2 (flooded twice) and 1.8 (flooded more than twice). This is slightly different outcome from the usual trend seen in the residential sector where it takes more than two or three times for the flood-affected population to understand the importance of mitigation [35]. In commercial sector it seems that those who decide to undertake mitigation activities choose to do so in the light of fewer events.

\subsection{Observed patterns of recovery}

Respondents were asked to rank between 1 and 5 (1-no cost incurred and 5 highly expensive) the different factors that affect cost of recovery. Table 3 illustrates the percentage of differential cost incurred by respondents based on their differential ranking.

Disruption of sales was scored highest while employee compensation and legal charges were among the lowest ranked factors. Other factors like clean up charges, machinery and sales disruption, working hour loss and repairing ranked among the next four most costly factors in terms of recovery. Out of $100 \%$ of total cost incurred $62 \%$ of the total cost was incurred for indirect flood impacts. Therefore, it is evident that the cost incurred on recovering from indirect sources of damage was more dominating than its counterpart. Answering questions regarding financing sources for recovery the responses were clearly dominated by two sources of finances; self- finance and property insurance. Table 3 indicates how 
Table 3: Differential ranking of importance of factors affecting cost of recovery.

\begin{tabular}{|l|c|c|}
\hline $\begin{array}{l}\text { Factors affecting cost of } \\
\text { recovery }\end{array}$ & $\begin{array}{l}\text { Ranking assigned as \% of total } \\
\text { cost of recovery }\end{array}$ & Rank \\
\hline Sales disruption & $13 \%$ & 2 \\
\hline Clean-up charge & $12 \%$ & 3 \\
\hline Machinery repair & $10 \%$ & 3 \\
\hline Supply disruption & $10 \%$ & 3 \\
\hline Work hour loss & $10 \%$ & 4 \\
\hline Repair inside buildings & $9 \%$ & 5 \\
\hline Structural repair & $8 \%$ & 6 \\
\hline Vacant property charges & $7 \%$ & 7 \\
\hline Data back up & $6 \%$ & 7 \\
\hline Unrecoverable rent & $6 \%$ & 8 \\
\hline Employee compensation & $5 \%$ & 8 \\
\hline Legal charges & $5 \%$ & \\
\hline
\end{tabular}

businesses responded to questions associated with financing the process of recovery. However the difference in their proportions clearly emphasize that businesses are still more reliant on self-finance rather than insuring their properties. This might be as a result of the general perception of risk among businesses where impact of flooding is considered as temporary.

There was another funding source indicated in the questionnaire, for instance, commercial loan but none of the respondents indicated that they have opted for this measure. Apart from self-finance and insurance the other factors accounted for only $5 \%$ indicating very low adaptation. In other words, more than 50\% (51\% of self-finance and other) of the business losses are hidden in the sense that they will not appear in official claims statistics from insurers and may not be recorded anywhere else. This suggests that estimates of disaster impacts on business communities may be rather lower than the true cost to businesses. The time taken by the businesses to recover from the effects of flooding was distributed among two categories, the short term recovery and long term recovery. Table 4 summarizes the short term and long term impacts on recovery from flooding. Less than $30 \%$ of the flooded businesses indicated insignificant effects on their businesses in short term and $23 \%$ in the long term; $38 \%$ of respondents indicated that they were able to get back to business within 1-3 days in short term and $10 \%$ in long term followed by $16 \%$ and $20 \%$ who took up to 7 days, $7 \%$ and $13 \%$ had to suffer for up to 20 days and the rest $9 \%$ and $23 \%$ took longer to recover partially from disruption.

Although people said that floods affected their businesses significantly many of the respondents responded that they were fully recovered within a month or so. 
Some businesses indicated that they can still feel the effects of flooding and never recovered completely. This was around $10 \%$ of the flood-affected sample. Therefore this might be possible that those businesses which could not recover from the impacts of flooding were not represented in this data because they might have closed or moved to another location. This is one of the drawbacks of selfadministered questionnaires to be fully explained, especially a questionnaire with such great detail of information. It is interesting to notice that the preparedness actions taken by businesses before flood event were mainly concentrated on reducing direct damages, however data indicated that the impact of indirect effect of flooding costs them more to recover. Therefore the insight gained from the empirical analysis suggests that attention in reducing effects of indirect disruptions and reducing impacts which originates offsite is also necessary.

Table 4: Sources of financing used by businesses for disaster recovery.

\begin{tabular}{|l|c|}
\hline Sources of funding for recovery & Percentage of total sources of financing $\%$ \\
\hline Self-finance & $51 \%$ \\
\hline Insurance + self-finance & $10 \%$ \\
\hline Insurance & $9 \%$ \\
\hline Business reserve & $3 \%$ \\
\hline Business reserve + self-finance & $3 \%$ \\
\hline Commercial loan & $0 \%$ \\
\hline No preparedness/no response & $25 \%$ \\
\hline
\end{tabular}

Table 5: Time taken by businesses to recover.

\begin{tabular}{|l|r|r|}
\hline Time for recovery & $\begin{array}{r}\text { Short term (\% of total time } \\
\text { required })\end{array}$ & $\begin{array}{r}\text { Long term (\% of total time } \\
\text { required })\end{array}$ \\
\hline Within 3 days & $38 \%$ & $10 \%$ \\
\hline Immediately & $30 \%$ & $23 \%$ \\
\hline Within a week & $16 \%$ & $20 \%$ \\
\hline Two weeks & $7 \%$ & $13 \%$ \\
\hline More than a month & $6 \%$ & $16 \%$ \\
\hline Month & $3 \%$ & $7 \%$ \\
\hline Year or more & $0 \%$ & $10 \%$ \\
\hline
\end{tabular}

The respondents were asked to rank between 1 and 5 (1 indicating recovered in no time and 5 indicating the highest time taken to recover) the factors affecting time of recovery. Cleaning up of properties (ranked highest in terms of time consumption) and bringing customers back $\left(2^{\text {nd }}\right)$ are the most time consuming factors that hinders businesses from operating well after disruption. Often the loss of work hour $\left(3^{\text {rd }}\right)$ could be accommodated by working more, but this results in payment of overtime and other inconveniences. For businesses which were affected directly, clean up and drying could take months especially if they do not have resilient fittings installed measures to protect the property from such effects before the occurrence of the event; and therefore, this further worsens the situation 
by losing more customers and work hour loss. Other factors such as repair inside building and supply disruption, machinery repair, structural damage and recovery services ranked $4^{\text {th }}, 5^{\text {th }}$ and $6^{\text {th }}$ respectively.

\section{Conclusion and recommendations}

This paper presented survey based evidence of property occupiers' experience on impacts of flooding, patterns of preparedness and recovery in the two selected case study areas in Wakefield and Sheffield. A comprehensive descriptive analysis obtained through collection of data by use of self-administered postal questionnaire from occupiers of business property in different flood risk categories indicated the current situation of preparedness and recovery persisting among flooded business communities at risk. Reflections obtained from this study illustrate that damage and disruption pattern is more skewed towards indirect factors. It was observed that in-spite of some level of preparedness among the flood-affected population against direct impacts, there is considerable lack of preparatory measures for indirect effects. There is a requirement of shift in attention towards preparedness against business interruption. It is important to focus on appropriate measures and efforts to adopt them in risk reduction process. Relatively little attention has been paid to conduct assessment of effects of flooding on properties with repeated flood experience. Based on the glimpse of interesting result obtained for repeat flooded property in terms of preparedness it is recommended that more research should be diverted towards deeper understanding of business properties with previous experience of flooding.

\section{References}

[1] Y. Zhang, M. K. Lindell, and C. S. Prater, "Vulnerability of community businesses to environmental disasters," Disasters, vol. 33, no. 1, pp. 3857, 2009.

[2] Committee on Disaster Research and Social sciences, "Facing Hazards and Disasters: Understanding Human Dimensions." National Academy Press., Washington D.C., 2006.

[3] K. Clemo, "Preparing for Climate Change: Insurance and Small Business.," Geneva Pap. Risk Insur. - Issues Pract., vol. 33, no. 1, pp. 110-116, Jan. 2008.

[4] M. Pitt, "The Pitt Review - Learning Lessons from the 2007 floods," Cabinet office, London, 2008.

[5] G. Wedawatta, B. Ingirige and D. Proverbs, "Adaptation to flood risk: the case of businesses in the UK," in International conference on building resilience, 2011.

[6] E. P. Evans, J. D. Simm, C. R. Thorne, N. W. Arnell, R. M. Ashley, T. M. Hess, S. N. Lane, J. Morris, R. J. Nicholls, E. C. Penning-Rowsell, N. S. Reynard, A. J. Saul, S. M. Tapsell, A. R. Watkinson, H. S. Wheater, "An update of the foresight future flooding 2004 qualitative risk analysis," Cabinet Office, London, 2008. 
[7] G. J. P. Strunz, K. Zosseder, S. Wegscheider, M. Mück, T. Riedlinger, H. Mehl, S. Dech, J. Birkmann, and H. Harjono N. Gebert, H. Z. Anwar, Sumaryono, R. M. Khomarudin and A. Muhari, "Tsunami risk assessment in Indonesia.," Nat. Hazards Earth Syst. Sci., vol. 11, pp. 67-82, 2011.

[8] R. Basher, "Global early warning systems for natural hazards: systematic and people-centred," Philos. T. Roy. Soc. A, vol. 181, no. 9, pp. 21672182, 2006.

[9] Committee on Disaster Research and Social Sciences, The Impacts of Natural Disasters. Washinton D.C.: National Academy Press, 1999.

[10] H. S. Wheater, "Flood hazard and management: a UK perspective," Philos. Trans. R. Soc. A Math. Phys. Eng. Sci., vol. 364, no. 1845, pp. 2135-2145, 2006.

[11] G. Peters-Guarin, M. K. McCall and C. van Westen, "Coping strategies and risk manageability: using participatory geographical information systems to represent local knowledge," Disasters, vol. 36, no. 1, pp. 1-27, 2012.

[12] M. Bleda and S. Shackley, "The dynamics of belief in climate change and its risks in business organisations," Ecol. Econ., vol. 66, no. 2-3, pp. 517532, 2008.

[13] H. Kreibich, M. Müller, A. H. Thieken and B. Merz, "Flood precaution of companies and their ability to cope with the flood in August 2002, Germany," Water Resourses. Res., vol. 43, no. W03408, 2007.

[14] J. M. Dahlhamer and M. J. D'Souza, "Determinants of Business Disaster preparedness in two U.S. Metropoliton areas," Int. J. Mass Emerg. Disasters, vol. 15, no. 2, pp. 265-281, 1997.

[15] B. Ingirige, D. Proverbs and G. Wedawatta, "Impact of flooding on SMEs and their relevance to Chartered Surveyors," RICS, London, 2012.

[16] D. Crichton, "Climate Change and its Effects on Small Businesses in the UK," AXA Insurance, London, 2006.

[17] A. Gissing, "Flood action plans - making loss reduction more effective in the commercial sector," Aust. J. Emerg. Manag., vol. 18, no. 3, pp. 1-9, 2003.

[18] F. Berkhout, J. Hertin and N. W. Arnell, "Business and Climate Change: Measuring and Enhancing Adaptive Capacity," Tyndall Centre, Technical Report 11, 2004.

[19] F. Messner and V. Meyer, "Flood damage, vulnerability and risk perception - challenges for flood damage research," Discussion paper. UFZ, Leipiz, 2005.

[20] B. Merz, H. Kreibich, R. Schwarze and A. Thieken, "Assessment of economic flood damage," Nat. Hazards Earth Syst. Sci., vol. 10, pp. 1697$1724,2010$.

[21] T. E. Drabek, "Understanding disaster warning responses," Soc. Sci. J., vol. 36, no. 3, pp. 515-523, 1999.

[22] D. Mileti, Designing Future Disasters: An Assessment and Bolder Course for the Nation. Washington: Joseph Henry Press., 1999. 
[23] P. D. Howe, "Hurricane preparedness as anticipatory adaptation: A case study of community businesses," Glob. Environ. Chang., vol. 21, no. 2, pp. 711-720, May 2011.

[24] A. Jha, J. Lamond, R. Bloch, N. Bhattacharya, N. Papachristodoulou, A. Bird, D. Proverbs, J. Davies and R. Baker, Cities and Flooding: A guide to integrated urban flood risk management for 21st Century. Washinton DC: GFDRR, World Bank, 2012.

[25] K. J. Tierney, "Business Impacts of the Northridge Earthquake," J. Contingencies Cris. Manag., vol. 5, no. 2, pp. 87-97, 1997.

[26] M. Aba-Bulgu and S.M.N. Islam, Corporate crisis and risk management: modelling strategies and SME application. Oxford: Elsevier Ltd., 2007.

[27] I. Seifert, H. Kreibich, B. Merz and A. H. Thieken, "Development of FLEMOcs-a new model for the estimation of flood losses in the commercial sector," Hydrol. Sci., vol. 55, no. 8, pp. 1302-1314, 2010.

[28] N. Bhattacharya and J. Lamond, "Flood Vulnerability and Hazard Adjustment of UK commercial sector : A synthesis of research," 2011.

[29] D. Wenk, "Is 'Good Enough' storage Good Enough for compliance?," Disaster Recover. J., vol. 17, no. 1, pp. 1-3, 2004.

[30] K. J. Tierney and R. G. Webb, "Business Vulnerability to earthquakes and other disasters," University of Delaware, DRC Preliminary papers, 2001.

[31] R. Raaijmakers, J. Krywkow and A. van der Veen, "Flood risk perceptions and spatial multi-criteria analysis: an exploratory research for hazard mitigation," Nat. Hazards, vol. 46, pp. 307-322, 2008.

[32] G. R. Webb, K. J. Tierney and J. M. Dahlhamer, "Predicting long-term business recovery from disasters: A comparison of the Loma Prieta earthquake and Hurricane Andrew," Environ. Hazards, vol. 4, no. 1, pp. 45-58, 2002.

[33] Environment Agency, "Flooding in England: A national assessment of flood risk." Bristol, 2009.

[34] Common Recognised Information Programme 45, "2007 Summer floods," 2007.

[35] C. Rose, D. G. Proverbs, C. Booth, C. and K. I. Manktelow, "Three times is enemy action - flood experience and flood perception," in Flood Recovery, Innovation and Response III, 2012. 